\title{
МЕЖВЕДОМСТВЕННОЕ ИНФОРМАЦИОННОЕ ВЗАИМОДЕЙСТВИЕ ПРИ ФОРМИРОВАНИИ ОБЪЕКТОВ ТЕРРИТОРИАЛЬНОГО ЗЕМЛЕУСТРОЙСТВА
}

\section{Ирина Анатольевна Басова}

Тульский государственный университет, 300600, Россия, г. Тула, пр. Ленина, 92, доктор технических наук, зав. кафедрой геоинженерии и кадастра, тел. (4872)73-44-28, e-mail: biajis20051@ya.ru

\section{Виктор Владимирович Чекулаев}

Тульский государственный университет, 300600, Россия, г. Тула, пр. Ленина, 92, кандидат технических наук, доцент кафедры геоинженерии и кадастра, тел. (4872)73-44-28, e-mail: chekulaev@mail.ru

\section{Алексей Викторович Бессмертный}

Управление градостроительства и архитектуры администрации г. Тулы, 300600, Россия, г. Тула, ул. Гоголевская, д.73, кандидат технических наук, референт отдела информационных систем, тел. (920)764-22-20, e-mail: bessmertny@mail.ru

Обсуждаются вопросы совершенствования межведомственного информационного взаимодействия в градостроительной деятельности.

Ключевые слова: межведомственное взаимодействие, государственные услуги, информационная система, градостроительная деятельность, реестр недвижимости

\section{FORMATION OF OBJECTS OF TERRITORIAL LAND MANAGEMENT: INTERDEPARTMENTAL INFORMATION INTERACTION}

\section{Irina A. Basova}

Tula State University, 92, Lenin Ave., Tula, 300600, Russia, D. Sc., Head of the Department of Geoengineering and Cadastre, phone: (4872)73-44-28, e-mail: biajis20051@ya.ru

\section{Victor V. Chekulaev}

Tula State University, 92, Lenin Ave., Tula, 300600, Russia, Ph. D., Associate Professor, Department of Geoengineering and Cadastre, phone: (4872)73-44-28, e-mail: chekulaev@mail.ru

\section{Alexey V. Bessmertny}

Department of Urban Planning and Architecture of the Administration of Tula, 73, Gogolevskaya, St., 300600, Russia, Ph. D., Referent, Department of Information Systems, phone: (920)764-22-20, e-mail: bessmertny@mail.ru

The issues of improving interdepartmental information interaction in urban development are discussed.

Keywords: interdepartmental interaction, public services, information system, urban development, real estate register

Анализ процессов предоставления государственных услуг в ходе реализации мероприятий административной реформы показал, что большинство государственных услуг предоставляются не только на одном из уровней власти и не 
только одним органом исполнительной власти. Гораздо чаще либо органу исполнительной власти, либо заявителю самостоятельно приходится взаимодействовать с другими органами исполнительной власти, государственными учреждениями и организациями. В большинстве случаев заявитель вынужден взаимодействовать с другими органами исполнительной власти и учреждениями для сбора исчерпывающего комплекта документов, необходимого для предоставления той или иной государственной или муниципальной услуги. И заявитель несет как временные, так и финансовые издержки. Вместе с тем, такое взаимодействие должно осуществляться органами исполнительной власти, предоставляющими такие услуги, самостоятельно для обеспечения качества и доступности государственных услуг.

На протяжении уже нескольких лет в России идет построение системы межведомственного взаимодействия в электронном виде (СМЭВ), целью которой является технологическое обеспечение информационного взаимодействия при предоставлении государственных и муниципальных услуг в электронной форме.

В соответствии с Постановлением Правительства РФ от 08.09.2010 г. № 697, СМЭВ представляет собой информационную систему, включающую информационные базы данных, программные и технические средства, обеспечивающие возможность доступа к электронным сервисам и взаимодействие информационных систем органов и организаций при предоставлении в электронной форме государственных и муниципальных услуг [1].

Основные функции СМЭВ заключаются в обеспечении передачи запросов, документов, сведений, необходимых для получения государственных и муниципальных услуг и поданных заявителями через единый портал, в подключенные к системе взаимодействия информационные системы органов и организаций, обязанных предоставить запрашиваемые государственные услуги; в обеспечении обмена электронными сообщениями между органами и организациями для передачи на единый портал запросов, документов и сведений, обработанных в информационных системах органов и организаций [2].

Однако, система СМЭВ, которая должна объединить в единое целое всех участников процесса оказания государственных и муниципальных услуг, пока находится в развитии.

В числе причин, по которым государственные и муниципальные услуги невозможно в полной мере предоставлять с использованием электронных сервисов присутствуют как технические проблемы, так и организационные, среди которых можно выделить:

- разрозненность и несовершенство информационных ресурсов региональных и муниципальных систем взаимодействия;

- отсутствие единой запросно-ответной системы;

- отсутствие защищенных каналов связи между задействованными во взаимодействии сторонами;

- проблемы с нормативно-правовым регулированием на федеральном уровне; 
- несвоевременный выпуск подзаконных актов, низкое качество разработанных административных регламентов для автоматизации процессов предоставления услуг и др.

С 2007 года в стране сформирован и продолжает совершенствоваться единственный законный инструмент идентификации и регистрации физических характеристик и признаков недвижимого имущества, содержащий систематизированный свод сведений о границах муниципальных образований, границах населенных пунктов, территориальных зонах и зонах с особыми условиями использования территорий и др. ЕГРН [3].

По данным ЕГРН создаются производные документы, предназначенные для осуществления информационного и межведомственного взаимодействия при решении задач управления земельными ресурсами, недвижимостью, территориями, что имеет особое значение для городов, характеризующихся многофункциональностью землепользования, множеством норм градостроительного регулирования и огромным количеством различных субъектов хозяйствования.

Правовое регулирование ведения ЕГРН осуществляет Федеральный закон от 13.07.2015 № 218-Ф3 «О государственной регистрации недвижимости» (далее - ФЗ 218) [4].

Статья 32 главы 4 Ф3 218 устанавливает случаи, по которым субъекты отношений по ведению ЕГРН обязаны взаимодействовать с органом регистрации прав. Так, органы государственной власти и местного самоуправления направляют в регистрирующий орган документы при принятии ими решений:

- об утверждении результатов государственной кадастровой оценки объектов недвижимости;

- об установлении или изменении разрешенного использования земельного участка;

- об утверждении правил землепользования и застройки либо о внесении изменений в правила;

- о переводе жилого (нежилого) помещения в нежилое (жилое) помещение;

- об установлении или изменении прохождения Государственной границы РФ, между субъектами РФ, границ населенного пункта, особо охраняемой природной территории, охотничьих угодий, зон территориального развития, территорий опережающего социально-экономического развития, лесничеств, лесопарков;

- об установлении, изменении или о прекращении существования зоны с особыми условиями использования территорий;

- о переводе земельного участка из одной категории земель в другую;

- об утверждении проекта межевания территории и др.

Законодательством установлен порядок взаимодействия информационной системы ведения ЕГРН с иными государственными и муниципальными информационными системами [5]. Обмен данными должен осуществляться на основе принципов обеспечения полноты и достоверности информации, предоставляе- 
мой и получаемой в рамках информационного взаимодействия [6]. Такое взаимодействие информационной системы ведения ЕГРН и других информационных систем реализуется на основе единой системы межведомственного электронного взаимодействия и подключаемых к ней региональных систем межведомственного электронного взаимодействия [7].

Для реализации муниципальной политики в области градостроительства, архитектуры и землеустройства, создания благоприятных условий для развития градостроительной деятельности и устойчивого развития территории муниципального образования управление градостроительства и архитектуры города Тула направляет для внесения сведений в Единый государственный реестр недвижимости документы:

- об установлении или изменении разрешенного использования земельного участка;

- об утверждении правил землепользования и застройки либо о внесении изменений в правила землепользования и застройки, если такими изменениями предусмотрено установление или изменение градостроительного регламента, установление или изменение границ территориальных зон;

- об установлении или изменении границ между субъектами Российской Федерации, границ муниципального образования, об установлении или изменении границ населенного пункта, установлении, изменении или о прекращении существования зоны с особыми условиями использования территорий;

- об утверждении проекта межевания территории.

Для ведения Информационной Системы Обеспечения Градостроительной Деятельности (АПК ИСОГД) используется аппаратно-программный комплекс.

В 2013 г. Правительством Тульской области было внедрено типовое решение для создания регионального сегмента электронного правительства (РСЭП). Одна из основных задач заключалась в создании единой автоматизированной системы приема, регистрации и выдачи необходимых документов организациям и гражданам при предоставлении государственных и муниципальных услуг для обеспечения доступа к услугам в режиме одного окна.

Основные запросы, формируемые управлением градостроительства и архитектуры при межведомственном взаимодействии, связаны с предоставлением сведений из ЕГРН (рис. 1).

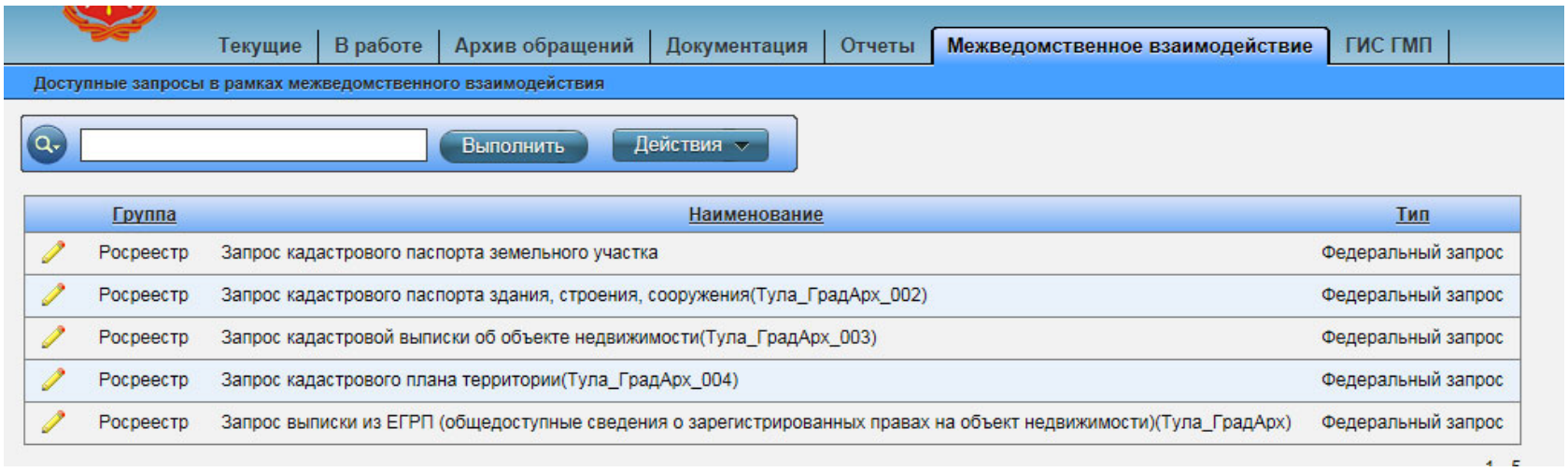

Рис. 1. Форма запроса при межведомственном взаимодействии 
Для подготовки документов в электронном виде и передачи согласно межведомственному информационному взаимодействию для внесения сведений в Единый государственный реестр недвижимости, управление градостроительства и архитектуры администрации города Тулы использует программный комплекс «ТехноКад-Муниципалитет», который является первым «облачным» геоинформационным сервисом в России для эффективного учета и управления земельными ресурсами и объектами капитального строительства.

Преимущество «облачной» платформы перед настольным решением заключается в том, что теперь пользователь «не привязан» к своему рабочему месту и ему не надо устанавливать специализированное программное обеспечение.

Программный комплекс позволяет формировать в одной заявке несколько сведений ЕГРН, что значительно упрощает получение информации (рис. 2).

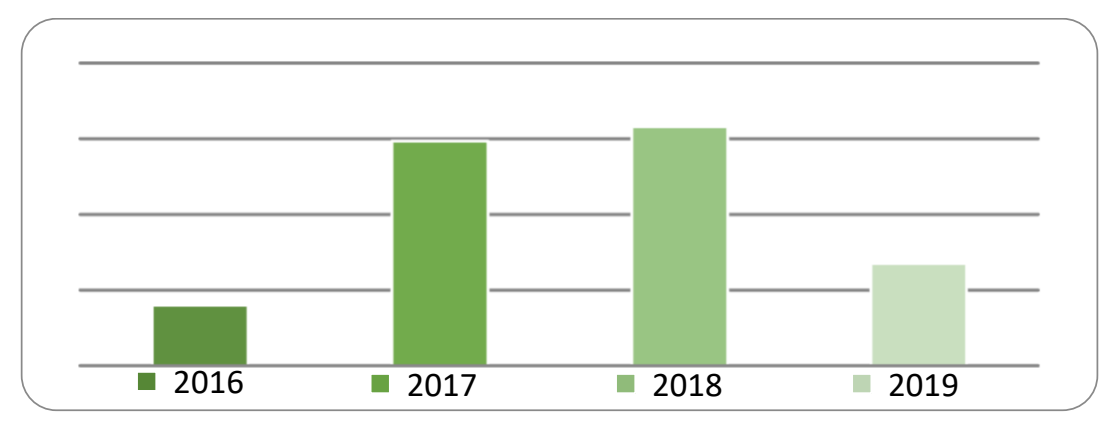

Рис. 2. Динамика запрошенных сведений ЕГРН с помощью информационных систем

Программный комплекс «ТехноКад-Муниципалитет» позволяет отправлять дополнительные документы, если есть замечания по постановке на кадастровый учет.

При передаче проектов межевания в филиал ФГБУ «ФКП Росреестра» по Тульской области согласно приказа № П/203 от 30.04.2014 электронные образы бумажных документов оформляются в виде файлов в формате PDF, подписанных усиленной квалифицированной электронной подписью лиц, которые в соответствии с нормативными правовыми актами Российской Федерации уполномочены заверять копии таких документов в форме документов на бумажном носителе, поскольку не разработана XML-схема электронного документа проекта межевания [7].

Для принятия решений структурных подразделений администрации города Тулы, а также для общего пользования разработан геоинформационный портал на основе MapServer, позволяющий публиковать открытые картографические данные в сети Интернет.

Совершенствование информационных систем обеспечения градостроительной деятельности при межведомственном информационном взаимодействии позволит снизить вероятность возникновения некорректной информации и повысит информационный, организационно-управленческий, экономический и правовой аспект принятия государственных и муниципальных решений [9]. 


\section{БИБЛИОГРАФИЧЕСКИЙ СПИСОК}

1. Постановление Правительства РФ от 08.09.2010 № 697 (ред. от 26.10.2017) «О единой системе межведомственного электронного взаимодействия» (вместе с «Положением о единой системе межведомственного электронного взаимодействия») // «Собрание законодательства РФ», 20.09.2010, № 38, ст. 4823.

2. Постановление Правительства РФ от 3 марта 2016 года №167 «О порядке информационного взаимодействия федеральной государственной информационной системы ведения Единого государственного реестра недвижимости с иными государственными или муниципальными информационными системами» (вместе c «Правилами информационного взаимодействия федеральной государственной информационной системы ведения Единого государственного реестра недвижимости с иными государственными или муниципальными информационными системами») // «Собрание законодательства РФ», 14.03.2016, № 11, ст. 1546.

3. Карпик А.П. О роли геоинформации в решении гражданско-правовых проблем на основе Единого государственного реестра недвижимости (На материалах Иркустуской области) / А.П. Карпик, Ю.В. Федоренко, Д.В. Пархоменко - Вестник СГУГиТ, Том 22, № 2, 2017, С. $154-170$.

4. Федеральный закон от 13.07.2015 № 218-Ф3 (ред. от 03.04.2018) «О государственной регистрации недвижимости» // «Собрание законодательства РФ», 20.07.2015, № 29 (часть I), ст. 4344. // «Российская газета», № 156, 17.07.2015.

5. Постановление Правительства РФ от 28.12.2011 № 1184 (ред. от 26.02.2016) «О мерах по обеспечению перехода федеральных органов исполнительной власти, государственных корпораций, наделенных соответствующими федеральными законами полномочиями по предоставлению государственных услуг, и органов государственных внебюджетных фондов на межведомственное информационное взаимодействие в электронном виде» (вместе с «Правилами обеспечения перехода федеральных органов исполнительной власти, государственных корпораций, наделенных соответствующими федеральными законами полномочиями по предоставлению государственных услуг, и органов государственных внебюджетных фондов на межведомственное информационное взаимодействие в электронном виде при предоставлении государственных услуг») // «Российская газета», № 2, 11.01.2012/.

6. Косых А.М. Практика реализации программ внедрения новых технологий в области государственного кадастрового учета и государственной регистрации прав на объекты недвижимости и сделок с ним / А.М. Косых - Москва, 2017.

7. Приказ от 30 апреля 2014 г. № п/203 Министерства экономического развития Российской Федерации «О размещении на официальном сайте федеральной службы государственной регистрации, кадастра и картографии в информационнотелекоммуникационной сети "интернет" требований к электронным образам бумажных документов, подписанных усиленной квалифицированной электронной подписью лиц, которые в соответствии с нормативными правовыми актами российской федерации уполномочены заверять копии таких документов в форме документов на бумажном носителе, представляемых органами государственной власти и органами местного самоуправления»,- http://www.consultant.ru.

8. Аврунев Е.И. Разработка информационной модели для повышения достоверности кадастровой информации / Е.И. Аврунев, М.П. Дорош - Землеустройство, кадастр и мониторинг земель, - Вестник СГУГиТ, Том 23, № 1, 2018. - С. 156-166.

(С) И. А. Басова, В. В. Чекулаев, А. В. Бессмертный, 2021 